\section{The Effect of Work Fulfilment on Job Characteristics and Employee Retention: Gen Y Employees}

Global Business Review $21(2) 1-15$

(C) 2018 IMI

SAGE Publications sagepub.in/home.nav DOI: I0.1 |77/0972| 509|87789|2 http://journals.sagepub.com/home/gbr

@SAGE

\author{
Koon Vui-Yee' \\ Khoo Paggy²
}

\begin{abstract}
Job characteristics are considered a contributing factor for the retention of employees at work, but the mechanism behind this relationship remains unclear. The current study aimed to analyse work fulfilment as mediators and age among Generation $Y$ (Gen $Y$ ) as moderators of the relationship between task and knowledge characteristics and employee retention based on self-determination theory (SDT). Data were collected from 153 Gen Y employees in Klang Valley, Malaysia and analysed using partial least squares (PLS). The results supported the predicted mediating role of work fulfilment with gender and educational level as control variables. Various ages among Gen $Y$ have no differences within the studied relationships. Implications, limitations of these findings and directions for future research are further discussed to improve the retention of employees in the workplace.
\end{abstract}

\title{
Keywords
}

Gen Y, work fulfilment, employee retention, job characteristics, task characteristics, partial least squares

\section{Introduction}

Generation Y (Gen Y), those born between 1977 and 2000, is slowly replacing the baby boomers and Generation X (Gen X) in the workplace. In Malaysia, for example, Gen Y employees currently comprise over half of the total labour force in the country (Department of Statistics Malaysia, 2015). Gen Y also has the shortest employment tenure, an average of 18 months, compared to the baby boomers and Gen $\mathrm{X}$ in the Asia-Pacific region (Queiri, Yusoff, \& Dwaikat, 2014). Gen Y employees reportedly expect employers to provide more and are more likely to leave a company if their needs and demands are not met (Dries, Pepermans, \& De Kerpel, 2008; Gursoy, Maier, \& Chi, 2008). As such, employee turnover is an issue in Asian countries (Chan \& Dar, 2014) and Malaysia, with an employee turnover rate of

\footnotetext{
' Senior Lecturer, Sunway University, No. 5, Jalan Universiti, Bandar Sunway, Selangor Darul Ehsan, Malaysia.

${ }^{2}$ Graduate, Sunway University, No. 5, Jalan Universiti, Bandar Sunway, Selangor Darul Ehsan, Malaysia.
} 
15.9 per cent, is ranked sixth for highest employee turnover rate in the Asia-Pacific region (Mohamad Nashuki, Othman, \& Ghazali, 2014).

Losing talented employees due to turnover affects a company's operation, as a recent study by Rahman et al. (2015) showed that a high employee turnover rate leads to a loss of knowledge and skills which eventually affects productivity, quality and profitability. With more talented employees leaving, new or inexperienced employees have to be hired to replace the former. Poor employee performance as a result of inexperience would also affect a company's efficiency. As mentioned previously, Gen Y currently populates the workplace and employees from this generation are prone to leave if their needs and demands are not satisfied. Hence, it is important to create recruitment and retention strategies that would match the work values of Gen Y in order to lower employee turnover rate.

Past studies have focused mainly on the factors for achieving job satisfaction, which includes salary, working hours, job promotion, job performance, rewards and penalties as well as skills and capabilities (Lambert, Hogan, \& Barton, 2001). However, a research gap exists as not many have looked into need fulfilment at work, which could be another factor influencing job satisfaction. A study by Freed (2003) investigated need fulfilment, in the form of work fulfilment, as a mediator of job satisfaction but did not clearly distinguish the factors that affect work fulfilment. Moreover, some researchers have concentrated on need fulfilment in the context of employer-employee relationships instead. For instance, a study by Liu, Hui, Lee, and Chen (2012) focused on the employer-employee psychological contract of fulfilment. The aforementioned studies helped us understand better about need fulfilment at the workplace but the ways in which need fulfilment, particularly work fulfilment, influences job characteristics and job behaviour remain unclear.

In this study, we defined job characteristics in terms of employees' task and knowledge characteristics at the workplace. Both task and knowledge characteristics are recognized as a form of job enrichment that facilitates high internal work motivation (Hackman \& Oldham, 1980) and indirectly affect employees' loyalty to a company (Niehoff, Moorman, Blakely, \& Fuller, 2001). Job behaviour examined in this study is employee retention, which is measured in the form of turnover intention. We proposed work fulfilment, when needs and demands expected from work are satisfied, to be a mediator in the relationship between the job characteristics and the job behaviour examined in this study. When expected needs and demands at work are met, task and knowledge characteristics may influence employees' intention to quit which would have an impact on employee turnover rate in a company.

We examined the job characteristics-employee retention relationship as mediated by work fulfilment based on the framework of self-determination theory (SDT). SDT suggests that autonomous motivation, which could be a result of work fulfilment, comprises intrinsic motivation and internalized extrinsic motivation (Deci \& Ryan, 2011). A combination of intrinsic and internalized motivation influences turnover intention. For example, if employees find their work-related needs satisfied, they are more likely to be self-motivated to work better and hence, less inclined to leave their workplace. Prior research on employee retention has been limited in the sense that it mostly examined the influence of organizational mission (Moncarz, Zhao, \& Kay, 2009), leadership (Chang, Wang, \& Huang, 2013) and human resource (HR) practices (Paré \& Tremblay, 2007) on turnover intention. The current study could potentially shed new light on the process underlying the job characteristics-employee retention relationship as we addressed the limitation of past studies by examining the role of work fulfilment as a mediator. Besides, we posited that age differences within Gen Y could be a moderating variable of our proposed model as researchers found more variation among members within a generation than there is between generations (Macky, Gardner, \& Forsyth, 2008). However, the majority of researchers studied the generational differences in terms of psychological traits (Twenge \& Campbell, 2008), career success (Dries et al., 2008) and work values (Gursoy et al., 2008), but all these studies were made in the comparison between generational. 
This study was an important one to conduct for several reasons. First, we integrated SDT in our study of the job characteristics-employee retention relationship, which could provide a clearer explanation on how job characteristics influence effective employee behaviour (i.e., reduced turnover intention). Second, we addressed the research gap pertaining to need fulfilment by incorporating work fulfilment as a mediator in the job characteristics-employee retention relationship. Work is an important basis of life (Zika \& Chamberlain, 1992), and it is through work that intrinsic motivation, which could be a form of job characteristics such as autonomy and competence, is satisfied (Celik, 2011). Employees are expected to experience work fulfilment when they perceive that their intrinsic motivation has been met (Celik, 2011). Third, we expanded the literature on job characteristics as we focused primarily on the influence of task and knowledge characteristics in a workplace, both of which are also a form of job enrichment. We used both formative and reflective models in our structural equation modelling. Using both models make stronger causality inferences as the first order were treated as formative constructs, while the factors of the second order were regarded as part of the reflective model. Fourth, turnover among Gen Y employees is a current issue faced by companies, particularly those in the Asia-Pacific region (Queiri et al., 2014), and our study could shed more light on this issue. Prior research had approached the job characteristics-employee retention relationship in contexts different from an Asian one; according to Katou and Budhwar (2012), context is an important factor to consider. Hence, our study examined the job characteristics-employee retention relationship specifically among Gen Y employees in an Asian context. In general, our findings could broaden our understanding of how exactly job characteristics influence turnover intention through work fulfilment, which could provide implications for handling employee turnover among Gen Y employees.

The first section of this article begins with the review of literature about job characteristics, employee retention, work fulfilment and Gen Y. We describe how work fulfilment mediates and age differences moderate between these variables. The second section presents the methodology used to test our proposed research model while the third section presents the results of our analyses. A discussion on these results is then presented in the fourth section. Finally, implications, limitations and suggestions for future research are presented in the last section.

\section{Review of Literature}

\section{Job Characteristics and Employee Retention}

Past studies found that job characteristics such as the authority to make decisions, autonomy, utilization of skills and conflict between role and work pressure affect work outcomes (Humphrey, Nahrgang, \& Morgeson, 2007). The current study examined job characteristics in terms of task and knowledge characteristics, which are also a form of job enrichment. Task characteristics, which consist of five core dimensions, namely, autonomy, task variety, task significance, task identity and task feedback, are the most frequently investigated type of job characteristics (Morgeson \& Humphrey, 2006). Knowledge characteristics are described as the knowledge, skill and ability that employees have in order to perform their jobs. Knowledge characteristics consist of job complexity, information processing, problem-solving, skill variety and specialization. Both characteristics can be treated either independent or integrated. Jobs can be designed or redesigned to enhance task demand, knowledge demand or a combination of the two as mentioned by Campion and McClelland (1993). Many studies (e.g., Garg \& Rastogi, 2006; Thomas, Buboltz, \& Winkelspecht, 2004) combined both characteristics of a job to determine work outcomes. For instance, several researchers have proposed that job design such as job characteristics has varying 
Global Business Review 2I(2)

impacts on employees' job satisfaction levels (Crede, Chernyshenko, Stark, Dalal, \& Bashshur, 2007; DeVaro, Li, \& Brookshire, 2007). Furthermore, a study by Thomas et al. (2004) measured the task characteristics only and found the four dimensions of task characteristics - autonomy, task variety, task identity and task feedback - influence job satisfaction. The first objective of our study is to determine whether perceived task and knowledge characteristics in work among Gen Y employees significantly influence employee retention.

\section{Work Fulfilment as a Mediator between Job Characteristics and Employee Retention}

Past research on the relationship between job characteristics and job behaviour had resulted in inconsistent findings. The effects of specific job characteristics on actual work behaviour, such as turnover, absenteeism and work effectiveness, have not been supported by a considerable number of studies (Hosie, Jayashree, Tchantchane, \& Lee, 2013) while the research focus on employee engagement is relatively new (Gupta \& Sharma, 2016). DeVaro's et al. (2007) re-examination of job characteristics in contemporary organizational contexts found no significant impact of contextual variables on employees' job satisfaction. Furthermore, a mediator was deemed an important variable as cognitive social capital was found to have mediated the relationship between autonomy and job satisfaction of Japanese and American workers (Yamaguchi, 2013). These mixed results indicated that more research is required to test the applicability of job characteristics along with careful consideration of contextual factors, particularly in contemporary organizations. There is also some merit in proposing an extended framework, with careful consideration of mediating factors, and the applicability of that framework in different contexts to establish the validity of job characteristics in relation to work-related outcomes such as turnover.

Some studies have used job satisfaction, work exhaustion (McKnight, Phillips, \& Hardgrave, 2009), work-family facilitation and family satisfaction (Mustapha, Ahmad, Uli, \& Iis, 2010) as mediators in measuring the relationship between job characteristics and work outcomes. These studies, however, have only focused on the job satisfaction level of employees without specifying Gen Y employees. Jusoh, Simun and Chong (2011) found that differences exist between what Gen Y employees expect to experience and what they actually experience in the workplace. This implies that the culture in most companies caters to the expectations of older generations and not those of Gen Y. It also indicates that the characteristics of Gen Y employees are distinct from those of older generations and hence, managing Gen Y employees using old methods may no longer be as effective. Lee, Hung and Ling (2012) concurred that Gen $\mathrm{Y}$ employees want jobs that fulfil extrinsic rewards and are also amenable to suit their materialistic and sophisticated lifestyle (Goh, 2012).

A recent study by Randstad UK (2014) found that Britain has a professional fulfilment issue whereby nearly 10 million employees declared dissatisfaction with their employers. Of the 29.84 million employees in the United Kingdom, 9.85 million of them were dissatisfied with their jobs. According to Lawler's theory of fulfilment, employees are happy only when their demands, wishes and needs are completely satisfied (Celik, 2011). This means that employees' perceived job enrichment in the form of task and knowledge characteristics could lead to work fulfilment and employees who feel fulfilled can positively impact turnover.

The idea that work fulfilment would lead to a positive impact is in line with SDT, which explains the emergence of autonomous motivation when employees internalize an activity's value into their sense of self. In other words, employees act from intrinsic motivation and internalized extrinsic motivation. For instance, when employees perceive that their task includes the freedom to make decisions (i.e., intrinsic motivation) and that this freedom fulfils their external goals and values (i.e., internalized 
extrinsic motivation), they become autonomously motivated and display more positive work-related attitudes (Gagné \& Deci, 2005). Thus, our second objective is to examine the mediating effect of work fulfilment between job characteristics (task and knowledge characteristics) and employee retention.

\section{Generation $Y$}

Gen Y has been defined in different ways, with Levenson (2010) describing Gen Y as comprising individuals born in the 1980s and 1990s whereas Thach and Olsen (2006) and Pickering and Cullen (2008) identified Gen Y as comprising those born between 1977 and 2000. To avoid confusion, this study defined Gen Y as individuals born between 1977 and 2000. In the workplace, Suleman and Nelson (2011) described Gen Y as providing competitive advantages to companies because Gen Y employees are highly educated, well-versed in technology, innovative and confident. On the other hand, Gen Y employees have also been found challenging to deal with as they not only demand clear instruction and instant feedback (Saxena \& Jain, 2012) but also has a short-term focus and low loyalty to companies (Petroulas, Brown, \& Sundin, 2010). Only a few studies have acknowledged generational differences in their research (Costanza, Badger, Fraser, Severt, \& Gade, 2012; Giancola, 2006; Parry \& Urwin, 2010). According to Sackett (2002), using generational differences for explanatory concepts may not be valid unless events and experiences causing cohort differences are clearly specified. As such, our study emphasized only on Gen Y instead of comparing Gen Y to other generations as Gen Y employees comprise more than half of the total labour force in Malaysia (Department of Statistics Malaysia, 2015). There is also a need to further examine the issue of employee turnover among Gen Y employees.

Age differences have been found to impact work-related variables. For instance, older and younger employees reportedly exhibit differences in physical ability (Maertens, Putter, Chen, Diehl, \& Huang, 2012), motivation (e.g., Kooij, De Lange, Jansen, Kanfer, \& Dikkers, 2011), job satisfaction (Ng \& Feldman, 2010) and personality characteristics (Twenge, Konrath, Foster, Campbell, \& Bushman, 2008) in the workplace. Therefore, we expected differences to also exist between those born earlier and those born later within the Gen Y cohort. Measuring age differences within the Gen Y cohort in terms of job characteristics, work fulfilment and their effect on employee retention would be more enlightening than using an unclear description of generational stereotypes to understand age differences at work (Cadiz, Truxillo, \& Fraccaroli, 2015). Hence, by distinguishing age in terms of those born in earlier years and those born in later years, our third objective is to study whether age difference (earlier or later) in Gen Y employees has a significant categorical moderating effect on the relationships among the variables in the research model.

\section{Methodology}

\section{Participants}

Participants were recruited from Klang Valley, Malaysia as this area is home to about 7.2 million people and is the second most competitive location for a global city in South East Asia (The Star, 2013). A total of 300 questionnaires were distributed manually and online to Gen Y employees from small- and medium-sized enterprises (SME) but only 153 completed and usable questionnaires (51\%) were returned. To explore the moderating effect of age, we categorized 73 respondents born between 1977 and 1989 as Earlier Gen Y and 80 respondents born between 1990 and 2000 as Later Gen Y. Majority of the 
respondents were below $26(52.3 \%)$ and were categorized as Later Gen Y while 47.7 per cent of the respondents were in Earlier Gen Y. There are 79 males (51.6\%) and 74 females (58.4\%) respondents. As for education level, the majority of the respondents were degree holders (34\%), followed by diploma holders (26.8\%). Respondents at the pre-universities level and master degree level were at a composition of 13.7 per cent and 10.5 per cent, respectively. The remaining respondents were at secondary certificate level and professional courses which composed only 6.5 per cent and 8.5 per cent, respectively.

\section{Measures}

The questionnaire sent to participants comprises measures on task and knowledge characteristics, work fulfilment and employee retention. For task and knowledge characteristics, the measures were adapted from Morgeson and Humphrey (2006) while the measure for work fulfilment was adapted from Twenge and King (2005). Employee retention, which is the dependent variable, is defined in terms of the participants' intention to quit the company. The measure for employee retention was adapted from SánchezManjavacas, Saorín-Iborra and Willoughby (2014). All items in the measures were rated on 5-point Likert scales, ranging from 1 (strongly disagree) to 5 (strongly agree).

A pilot study was conducted to validate the items in the measures of task, knowledge characteristics and work fulfilment. Cronbach's alpha values of more than 0.76 were reported for all items and hence, these items were retained in the questionnaire. In analysing the proposed relationships among the variables, the study aligned itself with past studies by controlling for participants' gender (e.g., Lyness \& Judiesch, 2001; Ostroff \& Atwater, 2003) and educational level (Rambur, McIntosh, Palumbo, \& Reinier, 2005).

\section{Analysis}

Partial least squares (PLS) analysis was used to evaluate the research model due to our obtained modest sample size. PLS is also the appropriate tool to test for formative factor models. First, we checked the outer model loadings and eliminated two items because the loadings were less than the recommended value of 0.50 (Hair, Black, Babin, \& Anderson, 2010). Subsequently, we checked the internal composite reliability (ICR) of all constructs and found the values to be between 0.71 and 0.95 . The average variance extracted (AVE) for all constructs were between 0.62 and 0.91 . Therefore, convergent validity was achieved as all values of ICR and AVE as shown in Table 1 were above the recommended value points of 0.70 and 0.50 , respectively. To check for discriminant validity, we measured the square root of the AVEs for each construct and found that they were greater than the correlations between constructs. This indicated that each construct is different from one another within the model. Table 1 shows that the square roots of the AVEs are higher than the row and column values, confirming discriminant validity.

The second-order model was first evaluated by examining the correlations among the dimensions of the task and knowledge characteristics. Results showed that both of these characteristics were statistically significant at $p<0.05$, with correlations of $r=0.524$ and $r=0.287$, respectively. The modest correlations of both characteristics suggested appropriate formative indicators. We assessed each path coefficient from first-order factors to second-order factors to check the convergent validity of secondorder factors. Figure 1 shows that each first-order factor was significantly related $(p<0.05)$ to its secondorder factor, except for the relationship between job complexity and knowledge characteristics which has a standardized path coefficient (0.096) lower than 0.10 . The rest of the standardized path 


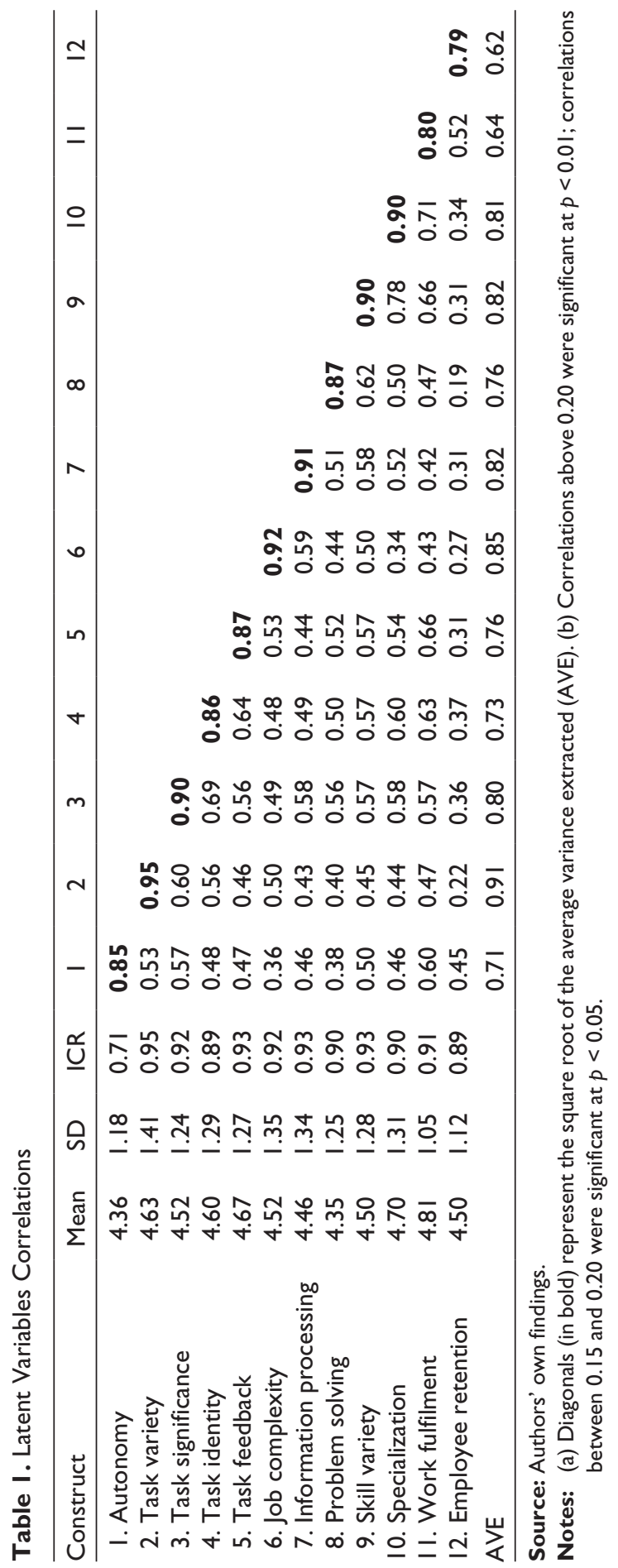




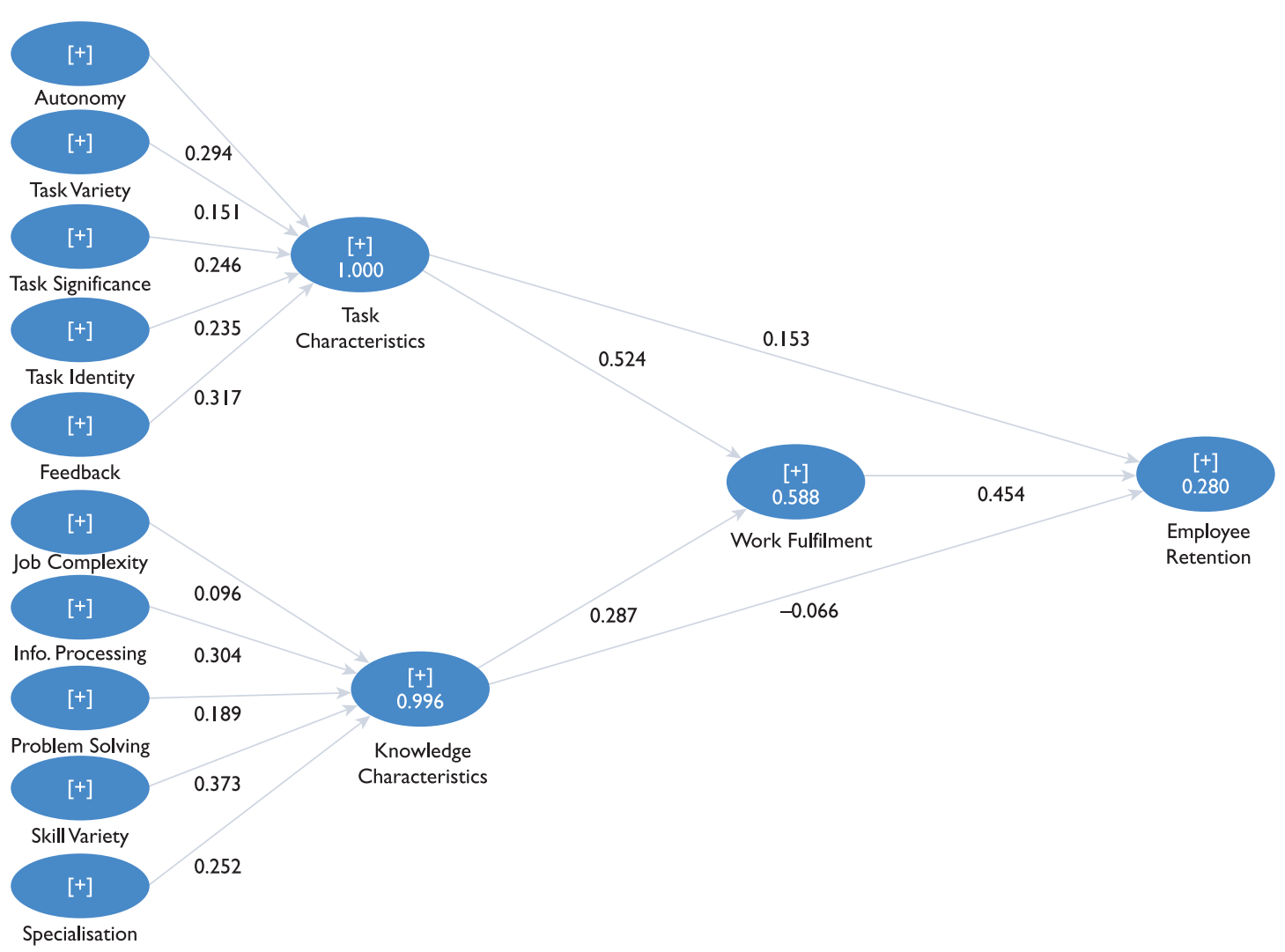

Figure I. Results of the Proposed Research Model

Source: Authors' own findings.

coefficients ranged between 0.15 and 0.37 , which were more than 0.10 . Overall, however, second-order factors appeared appropriate for our proposed research model.

\section{Structural Model}

The path coefficients of the structural model displayed in Figure 1 and Table 2 represent standardized betas. The structural model showed that neither task characteristics $(\beta=0.153 ; p=0.186)$ nor knowledge characteristics $(\beta=-0.066 ; p=0.583)$ predicted employee retention and thus, did not support the first objective of the study. However, both task characteristics $(\beta=0.524, p<0.001)$ and knowledge characteristics $(\beta=0.287 ; p<0.01)$ had significant relationships with work fulfilment. The path coefficient between work fulfilment and employee retention was significant as well $(\beta=0.454 ; p<0.001)$. These results suggest the possible mediating role of work fulfilment in the proposed model.

We conducted a mediation analysis following Preacher and Hayes' (2008) two-step procedure with bootstrapping. This procedure requires the direct effect of the independent variable on the dependent variable to be statistically significant first before proceeding with an analysis of the independent 
Table 2. Significance Testing Results of the Structural Model Path Coefficients

\begin{tabular}{lccc}
\hline Path & Path Coefficients & $t$-Values & $p$-Values \\
\hline TC $\rightarrow$ ER & 0.153 & 1.326 & 0.186 \\
TC $\rightarrow$ WF & 0.524 & 6.400 & 0.000 \\
KC $\rightarrow$ ER & -0.066 & 0.549 & 0.583 \\
KC $\rightarrow$ WF & 0.287 & 3.416 & 0.001 \\
WF $\rightarrow$ ER & 0.454 & 4.198 & 0.000 \\
\hline
\end{tabular}

Source: Authors' own findings.

Notes: $N=153 ; \mathrm{TC}=$ task characteristics, $\mathrm{ER}=$ employee retention, $\mathrm{WF}=$ work fulfilment and $\mathrm{KC}=$ knowledge characteristics.

Table 3. Mediation Analysis in Partial Least Squares-structural Equation Modelling

\begin{tabular}{|c|c|c|c|c|c|c|c|}
\hline Procedure & Path & $\beta$ & Indirect Effect & Std. Dev. & Total Effect & VAF & $t$-Values \\
\hline $\begin{array}{l}\text { Step I: Direct } \\
\text { effect (without } \\
\text { mediator) }\end{array}$ & $\mathrm{TC} \rightarrow \mathrm{ER}$ & 0.47 & - & - & - & - & $8.36^{* * * *}$ \\
\hline Step 2: Indirect & $\mathrm{TC} \rightarrow \mathrm{ER}$ & 0.13 & - & - & - & - & 1.18 (ns) \\
\hline $\begin{array}{l}\text { effect (with } \\
\text { mediator }\end{array}$ & $\begin{array}{l}\mathrm{TC} \rightarrow \mathrm{WF} \\
\mathrm{WF} \rightarrow \mathrm{ER}\end{array}$ & $\begin{array}{l}0.75 \\
0.43\end{array}$ & 0.32 & 0.05 & 0.45 & 0.711 & $6.4^{* * *}$ \\
\hline $\begin{array}{l}\text { Step I: Direct } \\
\text { effect (without } \\
\text { mediator) }\end{array}$ & $\mathrm{KC} \rightarrow \mathrm{ER}$ & 0.38 & - & - & - & - & $6.45^{* * * *}$ \\
\hline Step 2: Indirect & $\mathrm{KC} \rightarrow \mathrm{ER}$ & 0.002 & - & - & - & - & $4.44^{* * * * *}$ \\
\hline effect (with & $\mathrm{KC} \rightarrow \mathrm{WF}$ & 0.70 & 0.36 & 0.06 & 0.37 & 0.995 & 6.00 **** \\
\hline mediator) & $W F \rightarrow E R$ & 0.52 & & & & & \\
\hline
\end{tabular}

Source: Authors' own findings.

Notes: $N=153 ; * * * p<0.001$; ns $=$ non-significant.

variable's indirect effect on the dependent variable (via the mediator) and associated $t$-values. Table 3 displays the results of our mediation analysis. The direct effect of task characteristics $(\beta=0.47 ; p<$ $0.001)$ and knowledge characteristics $(\beta=0.38 ; p<0.001)$ on employee retention were found to be statistically significant, fulfilling the first step of the procedure. When work fulfilment (the mediator) was included in the model, the indirect effect of task characteristics $(\beta=0.32 ; t$-value $=6.4 ; p<0.001)$ and knowledge characteristics $(\beta=0.36 ; t$-value $=6.0 ; p<0.001)$ on employee retention were statistically significant as well. These results demonstrate the mediating effect of work fulfilment on the relationship between job characteristics (task and knowledge characteristics) and employee retention. The strength of the mediator was examined using the total effect and variance accounted for (VAF) value, which is calculated by dividing the sum of indirect effect value with the sum of total effect value. The results showed that 71.2 per cent of the effect of task characteristics on employee retention was attributed to work fulfilment as a mediator. However, the magnitude of the mediation is only a partial effect as the VAF value exceeded the 0.20 threshold level but is less than 0.80 (Hair, Ringle, \& Sarstedt, 2013). On the other hand, 99.5 per cent of the effect of knowledge characteristics on employee retention was attributed to work fulfilment as a mediator and the magnitude of the mediation is considered a full effect. These results indicate work fulfilment to be a mediator and thus, achieved our second objective. 
Table 4. MGA Test: Path Coefficients and PLS-MGA Values for Later Gen Y and Earlier Gen Y

\begin{tabular}{|c|c|c|c|c|c|c|}
\hline \multirow[b]{2}{*}{ Path } & \multicolumn{2}{|c|}{ Group I: Later Gen Y } & \multicolumn{2}{|c|}{ Group 2: Earlier Gen Y } & \multicolumn{2}{|c|}{ Group I vs Group 2} \\
\hline & pl & se $[p(I)]$ & $p 2$ & se $[p(2)]$ & $*|p(I)-p(2)|$ & $\begin{array}{c}t \text {-Value } \\
\text { ( } p \text {-value) }\end{array}$ \\
\hline $\mathrm{TC} \rightarrow \mathrm{ER}$ & 0.01 & 0.243 & 0.26 & 0.178 & 0.25 & $0.8 \mathrm{I}(0.79)$ \\
\hline WF $\rightarrow$ ER & 0.34 & 0.215 & 0.55 & 0.126 & 0.21 & $0.82(0.79)$ \\
\hline $\mathrm{KC} \rightarrow \mathrm{ER}$ & 0.06 & 0.213 & -0.01 & 0.164 & 0.07 & $0.59(0.28)$ \\
\hline $\mathrm{TC} \rightarrow \mathrm{WF}$ & 0.45 & 0.097 & 0.58 & 0.139 & 0.13 & $0.79(0.43)$ \\
\hline $\mathrm{KC} \rightarrow \mathrm{WF}$ & 0.40 & 0.101 & 0.20 & 0.137 & 0.20 & $1.23(0.22)$ \\
\hline
\end{tabular}

Source: Authors' own findings.

Notes: $p(I)$ refers to path coefficients of group I; $p(2)$ are path coefficients of group 2; se[p(I)] refers to standard error of $p(I)$, se $[p(2)]$ refers to standard error of $p(2)$; *the results in absolute value.

The PLS-based multi-group analysis (PLS-MGA) of the non-parametric approach as suggested by Keil et al. (2000) was used to answer our third objective. Modified two-independent sample $t$-tests were used to compare the path coefficients across two groups of data while the standard deviations of the path coefficients were calculated using bootstrapping. As we explored for the categorical moderating effect of age on our research model, we also tested for heterogeneity to avoid drawing inaccurate conclusions (Becker, Rai, Ringle, \& Völckner, 2013). The results in Table 4 show that none of the relationships tested had any significant differences. All path coefficients do not differ significantly as all $p$-values were more than 0.05 . Hence, age was not reported to have a moderating effect as no significant difference between Later Gen Y and Earlier Gen Y was found.

\section{Conclusion}

The current study aimed to investigate the job characteristics-employee retention relationship as mediated by work fulfilment among Gen Y employees in Malaysia. Contrary to past literature, our findings indicate that job characteristics, in terms of task and knowledge characteristics, alone do not affect employee retention among Gen Y employees. Work fulfilment was found to be a mediator in the job characteristics-employee retention relationship. In line with SDT, our findings highlight the importance of intrinsic motivation and internalized extrinsic motivation in the workplace. Our findings provide important empirical evidence for understanding the motivational basis for effective employee behaviour.

Our findings suggest that task and knowledge characteristics could make a positive impact on employee retention among Gen Y employees only if these characteristics lead to work fulfilment. These characteristics are a form of job enrichment and hence, it can be implied that job enrichment is an important factor for Gen Y employees especially, if the type of job enrichment is aligned with the employees' personal values. By establishing the mediating role of work fulfilment, our findings add on to the literature of industrial and organizational psychology in discussing the indirect effects of job characteristics on employee retention among Gen Y employees.

In terms of the moderating role of age, our findings did not identify any difference in results between Gen Y employees born earlier (between 1980 and 1989) and those born later (between 1990 and 1999). The mediated job characteristics-employee retention relationship among Gen Y employees was similar across all ages. Our findings, while contradictory to past literature, are in line with SDT. Regardless of 
age differences, Gen Y employees experience work fulfilment if they perceive their work activities to be in alignment with their personal values. As such, these employees might be more likely to stay in the company and have reduced turnover intention.

\section{Managerial Implications}

Our findings revealed that job enrichment indirectly led to reduced turnover intention through work fulfilment among Gen Y employees in Malaysia. Given the cost associated with employee turnover and retention programmes, companies need to prioritize work fulfilment for Gen Y employees by creating job characteristics that align with the employees' values or expectations. Most of the Gen Y employees from our study revealed a keenness to stay with a company if they find their job is enriching. Therefore, managers should communicate clearly the tasks, roles and responsibilities of the job to their employees to motivate them to stay in the company. A desirable place to work is a competitive edge over the other companies (Kashyap \& Rangnekar, 2016). Companies can enhance the 'right' environment by making the 'right' choices regarding management practices that fit chosen strategies or values (Tiwari \& Saxena, 2012). According to Cappelli and Neumark (2001), HR practices enhance organizational performance while workplace climate and employee retention are clearly linked. Therefore, well-designed job characteristics that are coupled with values and interests that suit employees promote employee retention.

\section{Limitations and Suggestions for Future Research}

The major limitation of the study is that data collected was at a specific point in time through self-report measures. As such, respondent error and method bias could have occurred. As recommended by Podsakoff, MacKenzie, Lee and Podsakoff (2003), our survey was conducted anonymously to reduce method bias. Additionally, we employed the Harman one-factor test, and the analysis showed that for 17 factors with eigenvalues over 1.0, the first factor explained only 40.5 per cent of the variance. As the first factor explained less than 50 per cent of the variance, method bias is not a major issue in this study.

The current study only focused on Gen Y employees in Malaysia and despite the country being a unique melting pot of various cultures and races, it might not be very representative of Asia. Future studies could extend our study by including samples from different similar Asian countries in order to generalize these findings. Furthermore, our findings imply that Gen Y employees have stronger intentions to remain with a company if they experience work fulfilment. As work fulfilment was found to be a mediator of the job characteristics-employee retention relationship, future studies should examine other possible variables as mediators such as organizational culture, work climate and personality traits. We also recommend future studies to conduct qualitative research in order to comprehend better the reasons why Gen Y employees choose to leave or remain in a company.

\section{Acknowledgements}

The authors are grateful to the anonymous referees of the journal for their extremely useful suggestions to improve the quality of the article: usual disclaimers apply.

\section{Declaration of Conflicting Interests}

The author(s) declared no potential conflicts of interest with respect to the research, authorship and/or publication of this article. 


\section{Funding}

The author(s) received no financial support for the research, authorship and/or publication of this article.

\section{References}

Becker, J. M., Rai, A., Ringle, C. M., \& Völckner, F. (2013). Discovering unobserved heterogeneity in structural equation models to avert validity threats. MIS Quarterly, 37(3), 665-694.

Cadiz, D. M., Truxillo, D. M., \& Fraccaroli, F. (2015). What are the benefits of focusing on generation-based differences and at what cost? Industrial and Organizational Psychology, 8(3), 356-362. doi:10.1017/iop.2015.49

Campion, M. A., \& McClelland, C. L. (1993). Follow-up and extension of the interdisciplinary costs and benefits of enlarged jobs. Journal of Applied Psychology, 78(3), 339-351.

Cappelli, P., \& Neumark, D. (2001). Do 'high-performance' work practices improve establishment-level outcomes? ILR Review, 54(4), 737-775. doi:10.2307/2696111

Celik, M. (2011). A theoretical approach to the job satisfaction. Polish Journal of Management Studies, 4, 7-14.

Chan, W. S., \& Dar, O. L. (2014). Boundaryless career attitudes, employability and employee turnover: Perspective from Malaysian hospitality industry. Research Journal of Applied Sciences, Engineering and Technology, 7(12), 2516-2523. doi:10.19026/rjaset.7.561

Chang, W.-J. A., Wang, Y.-S., \& Huang, T.-C. (2013). Work design-related antecedents of turnover intention: A multilevel approach. Human Resource Management, 52(1), 1-26. doi:10.1002/hrm.21515

Costanza, D. P., Badger, J. M., Fraser, R. L., Severt, J. B., \& Gade, P. A. (2012). Generational differences in workrelated attitudes: A meta-analysis. Journal of Business and Psychology, 27(4), 375-394.

Crede, M., Chernyshenko, O. S., Stark, S., Dalal, R. S., \& Bashshur, M. (2007). Job satisfaction as mediator: An assessment of job satisfaction's position within the nomological network. Journal of Occupational and Organizational Psychology, 80(3), 515-538. doi:10.1348/096317906X136180

Deci, E. L., \& Ryan, R. M. (2011). Self-determination theory. In P. A. M. Van Lange, A. W. Kruglanski, \& E. T. Higgins (Eds), Handbook of theories of social psychology (vol. 1, pp. 416-433). Thousand Oaks, CA: SAGE.

Department of Statistics Malaysia. (2015). Number of labour force by age group, Malaysia, 1982-2014. Retrieved from https://www.statistics.gov.my/dosm/uploads/files/3_Time\%20Series/Labour_1982-2014/4_TABLE4.pdf

DeVaro, J., Li, R., \& Brookshire, D. (2007). Analysing the job characteristics model: New support from a crosssection of establishments. The International Journal of Human Resource Management, 18(6), 986-1003. doi:10.1080/09585190701321211

Dries, N., Pepermans, R., \& De Kerpel, E. (2008). Exploring four generations' beliefs about career: Is 'satisfied' the new 'successful'? Journal of Managerial Psychology, 23(8), 907-928.

Freed, D. E. (2003). Material benefits, advancement, or fulfillment: A study into the causes and predictors of job satisfaction based on how people view their work. Journal of Applied Management and Entrepreneurship, $8(4), 116$.

Gagné, M., \& Deci, E. L. (2005). Self-determination theory and work motivation. Journal of Organizational Behavior, 26(4), 331-362. doi:10.1002/job.322

Garg, P., \& Rastogi, R. (2006). New model of job design: Motivating employees' performance. Journal of Management Development, 25(6), 572-587. doi:10.1108/02621710610670137

Giancola, F. (2006). The generation gap: More myth than reality. People and Strategy, 29(4), 32-37.

Goh, L. (2012, February). Why job-hoppers hop. The Star. Retrieved from http://www.thestar.com.my/news/ nation/2012/02/19/why-jobhoppers-hop/

Gupta, N., \& Sharma, V. (2016). Exploring employee engagement: A way to better business performance. Global Business Review, 17(3S), 45S-53S. doi:10.1177/0972150916631082

Gursoy, D., Maier, T. A., \& Chi, C. G. (2008). Generational differences: An examination of work values and generational gaps in the hospitality workforce. International Journal of Hospitality Management, 27(3), 448-458. doi:10.1016/j.ijhm.2007.11.002

Hackman, J. R., \& Oldham, G. R. (1980). Work redesign. Reading, MA: Addison-Wesley.

Hair, J. F., Black, W. C., Babin, B. J., \& Anderson, R. E. (2010). Multivariate data analysis: A global perspective. Upper Saddle River, NJ: Pearson. 
Hair, J. F., Ringle, C. M., \& Sarstedt, M. (2013). Editorial-partial least squares structural equation modeling: Rigorous applications, better results and higher acceptance. Long Range Planning, 46(1-2), 1-12.

Hosie, P., Jayashree, P., Tchantchane, A., \& Lee, B. S. (2013). The effect of autonomy, training opportunities, age and salaries on job satisfaction in the South East Asian retail petroleum industry. The International Journal of Human Resource Management, 24(21), 3980-4007. doi:10.1080/09585192.2013.829517

Humphrey, S. E., Nahrgang, J. D., \& Morgeson, F. P. (2007). Integrating motivational, social, and contextual work design features: A meta-analytic summary and theoretical extension of the work design literature. Journal of Applied Psychology, 92(5), 1332-1356. doi:10.1037/0021-9010.92.5.1332

Jusoh, M., Simun, M., \& Chong, S. C. (2011). Expectation gaps, job satisfaction, and organizational commitment of fresh graduates: Roles of graduates, higher learning institutions and employers. Education + Training, 53(6), 515-530. doi:10.1108/00400911111159476

Kashyap, V., \& Rangnekar, S. (2016). The mediating role of trust: Investigating the relationships among employer brand perception and turnover intentions. Global Business Review, 17(3S), 64S-75S. doi:10.1177/0972150916631083

Katou, A. A., \& Budhwar, P. S. (2012). The link between HR practices, psychological contract fulfillment, and organizational performance: The case of the Greek service sector. Thunderbird International Business Review, 54(6), 793-809. doi:10.1002/tie.21504

Keil, M., Tan, B. C. Y., Wei, K.-K., Saarinen, T., Tuunainen, V., \& Wassenaar, A. (2000). A cross-cultural study on escalation of commitment behavior in software projects. MIS Quarterly, 24(2), 299-325. doi:10.2307/3250940

Kooij, D. T. A. M., De Lange, A. H., Jansen, P. G. W., Kanfer, R., \& Dikkers, J. S. E. (2011). Age and work-related motives: Results of a meta-analysis. Journal of Organizational Behavior, 32(2), 197-225. doi:10.1002/job.665

Lambert, E. G., Hogan, N. L., \& Barton, S. M. (2001). The impact of job satisfaction on turnover intent: A test of a structural measurement model using a national sample of workers. The Social Science Journal, 38(2), 233-250. doi:10.1016/S0362-3319(01)00110-0

Lee, C. S., Hung, D. K. M., \& Ling, T. C. (2012). Work values of generation Y preservice teachers in Malaysia. Procedia-Social and Behavioral Sciences, 65, 704-710. doi:10.1016/j.sbspro.2012.11.187

Levenson, A. R. (2010). Millennials and the world of work: An economist's perspective. Journal of Business and Psychology, 25(2), 257-264. doi:10.1007/s10869-010-9170-9

Liu, J., Hui, C., Lee, C., \& Chen, Z. X. (2012). Fulfilling obligations: Why Chinese employees stay. The International Journal of Human Resource Management, 23(1), 35-51. doi:10.1080/09585192.2011.606119

Lyness, K. S., \& Judiesch, M. K. (2001). Are female managers quitters? The relationships of gender, promotions, and family leaves of absence to voluntary turnover. Journal of Applied Psychology, 86(6), 1167-1178. doi:10.1037//0021-9010.86.6.1167

Macky, K., Gardner, D., \& Forsyth, S. (2008). Generational differences at work: Introduction and overview. Journal of Managerial Psychology, 23(8), 857-861.

Maertens, J. A., Putter, S. E., Chen, P. Y., Diehl, M., \& Huang, Y.-H. E. (2012). 12 Physical capabilities and occupational health of older workers. In J. W. Hedge \& W. C. Borman (Eds), The Oxford handbook of work and aging (pp. 215-235). New York, NY: Oxford University Press.

McKnight, D. H., Phillips, B., \& Hardgrave, B. C. (2009). Which reduces IT turnover intention the most: Workplace characteristics or job characteristics? Information \& Management, 46(3), 167-174. doi:10.1016/j.im.2009.01.002

Mohamad Nashuki, N., Othman, M., \& Ghazali, H. (2014). Predictors of intention to stay for employees of casual dining restaurant in Klang Valley area. International Food Research Journal, 21(3), 863-871.

Moncarz, E., Zhao, J., \& Kay, C. (2009). An exploratory study of US lodging properties' organizational practices on employee turnover and retention. International Journal of Contemporary Hospitality Management, 21(4), 437458. doi:10.1108/09596110910955695

Morgeson, F. P., \& Humphrey, S. E. (2006). The work design questionnaire (WDQ): Developing and validating a comprehensive measure for assessing job design and the nature of work. Journal of Applied Psychology, 91(6), 1321-1339. doi:10.1037/0021-9010.91.6.1321

Mustapha, N., Ahmad, A., Uli, J., \& Iis, K. (2010). Job characteristics as antecedents of intention to stay and mediating effects of work family facilitation and family satisfaction among single mothers in Malaysia. International Journal of Business and Social Science, 1(3), 59-74. 
Ng, T. W. H., \& Feldman, D. C. (2010). The relationships of age with job attitudes: A meta-analysis. Personnel Psychology, 63(3), 677-718. doi:10.1111/j.1744-6570.2010.01184.x

Niehoff, B. P., Moorman, R. H., Blakely, G., \& Fuller, J. (2001). The influence of empowerment and job enrichment on employee loyalty in a downsizing environment. Group \& Organization Management, 26(1), 93-113. doi: $10.1177 / 1059601101261006$

Ostroff, C., \& Atwater, L. E. (2003). Does whom you work with matter? Effects of referent group gender and age composition on managers' compensation. Journal of Applied Psychology, 88(4), 725-740.

Paré, G., \& Tremblay, M. (2007). The influence of high-involvement human resources practices, procedural justice, organizational commitment, and citizenship behaviors on information technology professionals' turnover intentions. Group \& Organization Management, 32(3), 326-357. doi:10.1177/1059601106286875

Parry, E., \& Urwin, P. (2010). The impact of generational diversity on people management. In E. Parry \& S. Tyson (Eds), Managing an age-diverse workforce (pp. 95-111). London: Palgrave Macmillan.

Petroulas, E., Brown, D., \& Sundin, H. (2010). Generational characteristics and their impact on preference for management control systems. Australian Accounting Review, 20(3), 221-240. doi:10.1111/j.1835-2561.2010.00099.x

Pickering, G. J., \& Cullen, C. W. (2008, July). The influence of taste sensitivity and adventurousness on generation Y's liking scores for sparkling wine. Paper presented at the Proceedings of the Fourth International Conference of the Academy of Wine Business Research, Siena, Italy.

Podsakoff, P. M., MacKenzie, S. B., Lee, J. Y., \& Podsakoff, N. P. (2003). Common method biases in behavioral research: A critical review of literature and recommended remedies. Journal of Applied Psychology, 88(5), 879-903. doi:10.1037/0021-9010.88.5.879

Preacher, K. J., \& Hayes, A. F. (2008). Asymptotic and resampling strategies for assessing and comparing indirect effects in multiple mediator models. Behavior Research Methods, 40(3), 879-891.

Queiri, A., Yusoff, W. F. W., \& Dwaikat, N. (2014). Generation-Y employees' turnover: Work-values fit perspective. International Journal of Business and Management, 9(11), 199-213. doi:10.5539/ijbm.v9n11p199

Rahman, M. K., Zailani, S., Al-Mamun, A., Jan, M. T., Ameziane, A. M., \& Hazeez, A. O. (2015). The impact of salesperson's training on organizational outcomes. Journal of Scientific Research and Development, 2(8), 48-57.

Rambur, B., McIntosh, B., Palumbo, M. V., \& Reinier, K. (2005). Education as a determinant of career retention and job satisfaction among registered nurses. Journal of Nursing Scholarship, 37(2), 185-192.

Randstad UK. (2014). Fulfilment at work: A report from Randstad UK. Retrieved from https://www.randstad. co.uk/ugc/documents/ContentHub/Randstad\%20Fulfilment\%20Report\%202014_Client_Version.pdf

Sackett, P. R. (2002). The structure of counterproductive work behaviors: Dimensionality and relationships with facets of job performance. International Journal of Selection and Assessment, 10(1-2), 5-11. doi:10.1111/ $1468-2389.00189$

Sánchez-Manjavacas, Á., Saorín-Iborra, M. C., \& Willoughby, M. (2014). Internal employability as a strategy for key employee retention. Innovar, 24(53), 7-22.

Saxena, P., \& Jain, R. (2012). Managing career aspirations of generation Y at work place. International Journal of Advanced Research in Computer Science and Software Engineering, 2(7), 114-118.

Suleman, R., \& Nelson, B. (2011). Motivating the millennials: Tapping into the potential of the youngest generation. Leader to Leader, 2011(62), 39-44.

Thach, E. C., \& Olsen, J. E. (2006). Market segment analysis to target young adult wine drinkers. Agribusiness, 22(3), 307-322. doi:10.1002/agr.20088

The Star. (2013, January). The Klang Valley has finally arrived to be in a top spot in world business. Retrieved from http://www.thestar.com.my/news/nation/2013/01/02/the-klang-valley-has-finally-arrived-to-be-ina-top-spot-in-world-business/

Thomas, A., Buboltz, W. C., \& Winkelspecht, C. S. (2004). Job characteristics and personality as predictors of job satisfaction. Organizational Analysis, 12(2), 205-219. doi:10.1108/eb028993

Tiwari, P., \& Saxena, K. (2012). Human resource management practices: A comprehensive review. Pakistan Business Review, 9(2), 669-705.

Twenge, J. M., \& Campbell, S. M. (2008). Generational differences in psychological traits and their impact on the workplace. Journal of Managerial Psychology, 23(8), 862-877. 
Twenge, J. M., \& King, L. A. (2005). A good life is a personal life: Relationship fulfillment and work fulfillment in judgments of life quality. Journal of Research in Personality, 39(3), 336-353. doi:10.1016/j.jrp.2004.01.004

Twenge, J. M., Konrath, S., Foster, J. D., Campbell, K. W., \& Bushman, B. J. (2008). Egos inflating over time: A cross-temporal meta-analysis of the Narcissistic Personality Inventory. Journal of Personality, 76(4), 875-902. doi:10.1111/j.1467-6494.2008.00507.x

Yamaguchi, I. (2013). A Japan-US cross-cultural study of relationships among team autonomy, organizational social capital, job satisfaction, and organizational commitment. International Journal of Intercultural Relations, 37(1), 58-71. doi:10.1016/j.ijintrel.2012.04.016

Zika, S., \& Chamberlain, K. (1992). On the relation between meaning in life and psychological well-being. British Journal of Psychology, 83(1), 133-145. 